\title{
Validation of an exercise booklet for children with acute lymphoblastic leukemia
}

\author{
Validação de cartilha de orientação \\ de exercícios para crianças \\ com leucemia linfoide aguda
}

Rafaela Ester Galisteu da Silva (10 ${ }^{1 *}$

Romeu Paulo Martins Silva (1) ${ }^{2}$

Ariane Ferreira Machado Avelar (10 ${ }^{3}$

${ }^{1}$ Universidade Federal do Acre (UFAC), Rio Branco, AC, Brazil

2 Universidade Federal de Catalão (UFCAT), Catalão, GO, Brazil

${ }^{3}$ Universidade Federal de São Paulo (UNIFESP), São Paulo, SP, Brazil

Date of first submission: August 7, 2020

Last received: September 25, 2020

Accepted: October 14, 2020

Associate editor: Ana Paula Cunha Loureiro

*Correspondence: rafagalisteu@hotmail.com

\begin{abstract}
Introduction: Leukemia is the most common childhood cancer, and acute lymphoblastic leukemia (ALL) accounts for 75 to $80 \%$ of all such cases in this population. Survival has increased among children and adolescents due to advances in diagnosis and treatment, with a growing emphasis on the need for rehabilitation to improve functionality and quality of life, mitigating the long-term effects of treatment. Objective: To describe the process of compiling and validating an exercise booklet for children and adolescents during and after treatment for acute lymphoblastic leukemia. Methods: Methodological study using the Delphi technique for validation. The panel of experts consisted of seven healthcare professionals and three mothers of children without ALL. The booklet was evaluated using a form containing 15 items scored on a 5-point Likert scale, and by qualitative assessment. The frequency of the expert ratings, percentage agreement and content validity index (CVI) were presented for each item and the instrument as a whole. Analyses were performed in R 3.5.1 software. Results: The booklet containing stretching, aerobics, strength and relaxation exercises was validated in the second round, reaching $100 \%$ consensus. When assessed only by the mothers, 93.33\% consensus was achieved in a single round. Conclusion: The exercises booklet was validated for use in the population studied.
\end{abstract}

Keywords: Acute lymphoblastic leukemia. Adolescents. Children. Physical exercise. Validation studies. 


\section{Resumo}

Introdução: A leucemia é o tipo mais comum de neoplasia na população infantil, sendo que a leucemia linfóide aguda representa 75 a $80 \%$ de todos os casos de leucemia nessa população. O aumento da sobrevida das crianças e adolescentes com câncer vem ocorrendo devido a avanços no diagnóstico e tratamento, destacando-se cada vez mais a necessidade de reabilitação para melhora da funcionalidade e qualidade de vida, reduzindo os impactos do tratamento a longo prazo. Objetivo: Descrever o processo de elaboração e validação de cartilha de orientação de exercícios em crianças e adolescentes durante e após tratamento de leucemia linfóide aguda. Métodos: Estudo metodológico, utilizando a técnica Delphi para validação. O painel de especialistas contou com sete profissionais da saúde e três mães de crianças sem leucemia linfoide aguda. A avaliação foi feita através de formulário composto por 15 itens, em escala tipo Likert, e avaliação qualitativa. Foram apresentadas as frequências das respostas dos avaliadores, a proporção de concordância e o índice de validade de conteúdo (IVC) para cada item e para o instrumento como um todo. As análises foram realizadas no software livre R 3.5.1. Resultados: $A$ cartilha composta de exercícios de alongamento, aeróbicos, de força muscular e de relaxamento foi validada na segunda rodada, atingindo $100 \%$ de consenso. Na avaliação das mães, obteve-se consenso de 93,33\% em única rodada. Conclusão: $A$ cartilha de orientação de exercícios físicos foi considerada validada para utilização na população estudada.

Palavras-chave: Leucemia linfoide aguda. Adolescentes. Crianças. Exercício físico. Estudos de validação.

\section{Introduction}

Leukemia is the most common childhood cancer worldwide, representing $30 \%$ of all tumors that occur under the age of 15 years. ${ }^{1}$ Acute lymphoblastic leukemia (ALL) accounts for 75 to $80 \%$ of all cases of leukemia in children and adolescents, with a wide range of clinical and biological aspects, and involves the proliferation, accumulation and infiltration of lymphoid blasts that overtake the bone marrow, lowering the number of red blood cells and resulting in complications such as anemia, hemorrhage and infections. ${ }^{2,3}$

Although treatments for childhood cancer have been increasingly successful, there are significant long-term complications. Physical impairments after cancer therapy contribute to a sedentary lifestyle and reduce cardiopulmonary and musculoskeletal function. ${ }^{4}$

Assessment of childhood cancer survivors (CCSs) five years after diagnosis and comparison of their physical performance with that of their siblings indicated that CCSs scored below their siblings in lower-extremity strength tests, timed up-and-go (TUG) and 6-minute walk tests (6MWT), despite reporting similar habitual levels and types of physical activity. ${ }^{4}$

In addition to reduced musculoskeletal and functional capacity, a study conducted in Turkey analyzed physical problems and symptoms in 91 children and adolescents after one to five years of treatment and identified the most common as being exercise intolerance (45.1\%), pain $(41.8 \%)$, respiratory system infections (40.7\%), fatigue (29.7\%), reduced bone mineral density (26.4\%), urinary tract infection (19.8\%) and obesity (18.7\%). ${ }^{5}$

Survival has increased among children and adolescents with cancer due to advances in diagnosis and treatment, with a growing emphasis on the need for rehabilitation to improve functionality, independence, social inclusion and quality of life. ${ }^{6}$ Exercise and physical therapy can decrease critical impairments that generally develop during and after cancer treatment. ${ }^{7}$

Studies have shown the positive effects of exercise on the quality of life of these patients, as well as physical and psychological aspects. ${ }^{8-12}$

Despite its proven benefits, there is still no established exercise protocol for children and adolescents. Inconsistencies regarding the type, frequency and duration of exercise further hamper its prescription by healthcare professionals. Although physical activity cannot be standardized, guidelines and evidence are needed to improve collaboration between professionals in prescribing physical exercise for these patients, with a focus on improving quality of life and self-esteem. ${ }^{13}$

Given the importance of exercise as a form of rehabilitation, the difficulties involved in systematizing these activities as well as adherence and motivation, the use of printed educational material combined with verbal instructions has become an effective method to facilitate patient understanding and participation. ${ }^{14}$

In light of the above, this study aimed to describe the process of compiling and validating an exercise booklet for children and adolescents during and after treatment for acute lymphoblastic leukemia. 


\section{Methods}

The methodological approach consisted of the following stages: literature review, compilation of the booklet, content validity assessment by experts using the Delphi technique, and evaluation by mothers of children without ALL on using the material.

The exercises included in the booklet were based on the recommendations of the South American Guidelines for Cardiovascular Disease Prevention and Rehabilitation $^{15}$ and Brazilian Cardiology Society's Cardio-Oncology Pediatric Guidelines ${ }^{16}$, as well as scientific articles on physical exercise and pediatric oncology ${ }^{10,17-21}$, used to establish the phases, intensity, duration, frequency and type of exercise.

The pictures were created by the authors on the Pixton ${ }^{\circledR}$ website and the exercises chosen based on the target population of children and adolescents and considering the chemotherapy phase and the first five years after treatment, as well as the main muscle groups targeted and total execution time.

The content was validated by a panel of experts consisting of healthcare professionals, using the Delphi technique 22,23 and according to clinical knowledge in the field of pediatric oncology and in the areas of training exercise and rehabilitation.
The experts were identified by analyzing the resumes on the Lattes Platform, inserting the following terms into the "subject" field: pediatric oncology physiotherapy, physical training in pediatric oncology, physical education in pediatric oncology, and pediatric oncology. Selection was intentional, considering the fields of medicine, nursing, physical therapy and physical education, as well as academic experience and professional career in pediatric oncology. In physical therapy and physical education, experience in training, exercise physiology and cardiovascular rehabilitation in the field of pediatric oncology were deemed important. Twelve professionals were invited to participate by email and provided with information on the study and the purpose of the booklet, a consent form, and booklet assessment form.

The first section of the booklet assessment form contained sociodemographic data about the participants and the second consisted of 15 questions about the objective of the booklet, general theoretical information, organization, presentation, exercise descriptions, pictures and general layout. The items were rated on a 5-point Likert scale, with five possible scores: 1-completely adequate; 2-adequate; 3-somewhat adequate; 4-inadequate; 5-no opinion, as shown in Figure 1. The form was compiled by the researcher based on a model from a study that also assessed and validated an educational booklet. ${ }^{24}$

\begin{tabular}{|c|c|c|c|c|c|}
\hline Items & & & atin & & \\
\hline $\begin{array}{l}\text { 1. Are the guidelines regarding limitations and/or contraindications for exercise appropriate for children } \\
\text { undergoing maintenance therapy? }\end{array}$ & 1 & 2 & 3 & 4 & 5 \\
\hline 2. Does the booklet achieve its objective of providing support and guidance for home exercises? & 1 & 2 & 3 & 4 & 5 \\
\hline 3. Is the booklet suitable for use by parents or guardians? & 1 & 2 & 3 & 4 & 5 \\
\hline 4. Is the booklet suitable for use by children and adolescents? & 1 & 2 & 3 & 4 & 5 \\
\hline 5. Is the wording used in the guidelines and picture descriptions clear and objective? & 1 & 2 & 3 & 4 & 5 \\
\hline 6. Do the exercises cover the main muscle groups? & 1 & 2 & 3 & 4 & 5 \\
\hline 7. Do the exercises follow a logical order? & 1 & 2 & 3 & 4 & 5 \\
\hline 8. Is the writing easy to understand? & 1 & 2 & 3 & 4 & 5 \\
\hline 9. Are the cover and title page visually appealing and is the provided information adequate? & 1 & 2 & 3 & 4 & 5 \\
\hline 10. Is the booklet well formatted (font, font size, general layout and appearance)? & 1 & 2 & 3 & 4 & 5 \\
\hline 11. Do the pictures accurately depict the correct position for the exercise? & 1 & 2 & 3 & 4 & 5 \\
\hline 12. Are the exercise descriptions easy to understand? & 1 & 2 & 3 & 4 & 5 \\
\hline 13. Is the order of the pictures (exercises) adequate? & 1 & 2 & 3 & 4 & 5 \\
\hline 14. In general, does the layout of the booklet achieve its objective simply and functionally? & 1 & 2 & 3 & 4 & 5 \\
\hline 15. Is the booklet relevant? & 1 & 2 & 3 & 4 & 5 \\
\hline
\end{tabular}

Figure 1 - Booklet assessment form. Source: research file. 
Concomitantly to the expert assessment, three mothers were invited the evaluate the booklet and its applicability. They were chosen intentionally, based on the following inclusion criteria: mothers of children without ALL and who are not health workers. They evaluated the booklet using the same form as the experts and then gave it to their children to follow the proposed exercise program.

Mothers of children without ALL were selected because the initial objective of this stage of the assessment was to evaluate the applicability of the booklet and understanding of the exercises based on their execution and the language and pictures used, regardless of health status.

The characterization data for the experts are presented as absolute frequencies, means and standard deviations. The booklet assessment results were analyzed considering the frequencies of ratings for each item on the form and the total number of items, as well as percentage agreement between experts. The content validity index (CVI) was expressed as the ratio between the number of items rated "completely adequate" and "adequate" and the total number of assessments performed. The CVI was calculated for each item on the form (partial CVI) and the instrument as a whole (total CVI), with values greater than or equal to $80 \%$ considered for validation. Analyses were conducted using R 3.5.1 software.

The booklet validation process was part of a doctoral study for the Paulista School of Nursing entitled "Effects of an exercise program on the physical fitness and quality of life of children and adolescents with acute lymphoblastic leukemia", and was approved by the institutional Research Ethics Committee (CAAE: 58867116.3.0000.5505E) under protocol no. 1.751.878.

\section{Results}

The booklet contains 20 exercises, arranged as follows: A) eight stretching exercises to warm up; B) training phase: two aerobic exercises, with one also targeting balance, one balance exercise and six strength exercises; C) three stretching and relaxation exercises at a lower intensity than the previous stage. Before describing the exercises, the booklet provides guidance and information on how to do the exercises safely, including ideal locations, staying hydrated, appropriate clothing and correct execution, as well as signs and symptoms that preclude children from exercising, as shown in in the supplementary document Exercise booklet.

Seven experts took part in the first round of the Delphi panel to assess the content validity of the booklet, but two were unavailable for the second round, which consisted of five experts.

Table 1 presents the characteristics of the panel. The experts were predominantly women and consisted of three physical therapists, two nurses, a physical education professional and a doctor. The majority had extensive professional experience and worked in clinical practice at the time of the study.

Table 1 - Characterization of the experts on the Delphi panel (Rio Branco, AC, Brazil, 2018)

\begin{tabular}{lcc}
\hline Characteristics & Round 1 (*n=7) & Round 2 (*n=5) \\
\hline Sex & 6 & 5 \\
Women & 1 & - \\
Men & $39.6 \pm 10.3$ & $40.8 \pm 10.3$ \\
Age $^{\star \star}$ & $17.3 \pm 11.8$ & $19.2 \pm 13.7$ \\
\hline Time since graduation $^{\star \star}$ & $15.9 \pm 12.2$ & $17.2 \pm 14.5$ \\
Career span $^{\star \star}$ & & \\
\hline Area of expertise & 3 & 2 \\
Physical Therapy & 2 & 2 \\
Nursing & 1 & - \\
Physical education & 1 & 1 \\
Medicine & & \\
\hline Academic Degree & 2 & 3 \\
Doctorate & 4 & - \\
Master's & 1 & \\
Specialization Course & & \\
\hline
\end{tabular}

Note: ${ }^{*} \mathrm{n}=$ sample size; ${ }^{* \star}$ mean \pm standard deviation, years. Source: the authors.

Table 2 shows the frequency of expert ratings, percentage of interrater agreement, total and partial CVIs for both assessment rounds.

None of the items were rated "inadequate" in either round. The CVI per item (partial) ranged from 57.1 to $100 \%$ in round 1, with all items obtaining $100 \%$ in the second round. The items with $\mathrm{CVI}<80 \%$ (questions 4, 5, 6, 11 and 12) were related to language, particularly technical terminology, pictures that did not adequately illustrate 
the exercises, questions regarding the execution of some exercises and execution time. The total CVI, considered the percentage of items rated "completely adequate" or "adequate", was $82.9 \%$ in round 1 and $100 \%$ in round 2, indicating group consensus for the booklet assessed.

The average age of the mothers who participated was $34 \pm 1.73$ years, with one working as a social educator, one psychologist and a housewife. They asked their children (average age of $8.67 \pm 3.21$ years) to perform the exercises, initially using only the pictures without reading the instructions, and observed whether they understood and executed them correctly. The mother's assessments were positive and the pictures the children found most difficult to understand were the same as those identified by the experts, which were then modified for round two.

Table 2 - Absolute frequency of booklet ratings, interrater agreement (\%) and content validity index (CVI) for each round of the Delphi panel (Rio Branco, AC, Brazil, 2018)

\begin{tabular}{|c|c|c|c|c|c|c|c|c|c|c|c|c|}
\hline \multirow{3}{*}{ Item } & \multicolumn{12}{|c|}{ Rating } \\
\hline & \multicolumn{2}{|c|}{ Completely adequate } & \multicolumn{2}{|c|}{ Adequate } & \multicolumn{2}{|c|}{ Somewhat adequate } & \multicolumn{2}{|c|}{ Inadequate } & \multicolumn{2}{|c|}{ No opinion } & \multicolumn{2}{|c|}{$\S \mathrm{CVI}(\%)^{*}$} \\
\hline & tR1 & †R2 & tR1 & †R2 & tR1 & $\ddagger \mathbf{R} 2$ & tR1 & ‡R2 & tR1 & $\ddagger \mathbf{R} 2$ & tR1 & $\neq \mathbf{R} 2$ \\
\hline 1 & $3(42.9)$ & $4(80.0)$ & $4(57.1)$ & $1(20.0)$ & $0(0.0)$ & $0(0.0)$ & $0(0.0)$ & $0(0.0)$ & $0(0.0)$ & $0(0.0)$ & 100.0 & 100.0 \\
\hline 2 & $3(42.9)$ & $4(80.0)$ & $3(42.9)$ & $1(20.0)$ & $1(14.3)$ & $0(0.0)$ & $0(0.0)$ & $0(0.0)$ & $0(0.0)$ & $0(0.0)$ & 85.7 & 100.0 \\
\hline 3 & $4(57.1)$ & $4(80.0)$ & $2(28.6)$ & $1(20.0)$ & $1(14.3)$ & $0(0.0)$ & $0(0.0)$ & $0(0.0)$ & $0(0.0)$ & $0(0.0)$ & 85.7 & 100.0 \\
\hline 4 & $2(28.6)$ & $3(60.0)$ & $2(28.6)$ & $2(40.0)$ & $3(42.9)$ & $0(0.0)$ & $0(0.0)$ & $0(0.0)$ & $0(0.0)$ & $0(0.0)$ & 57.1 & 100.0 \\
\hline 5 & $1(14.3)$ & $4(80.0)$ & $3(42.9)$ & $1(20.0)$ & $3(42.9)$ & $0(0.0)$ & $0(0.0)$ & $0(0.0)$ & $0(0.0)$ & $0(0.0)$ & 57.1 & 100.0 \\
\hline 6 & $4(57.1)$ & $3(60.0)$ & $1(14.3)$ & $2(40.0)$ & $1(14.3)$ & $0(0.0)$ & $0(0.0)$ & $0(0.0)$ & $1(14.3)$ & $0(0.0)$ & 71.4 & 100.0 \\
\hline 7 & $5(71.4)$ & $3(60.0)$ & $2(28.6)$ & $2(40.0)$ & $0(0.0)$ & $0(0.0)$ & $0(0.0)$ & $0(0.0)$ & $0(0.0)$ & $0(0.0)$ & 100.0 & 100.0 \\
\hline 8 & $2(28.6)$ & $3(60.0)$ & $5(71.4)$ & $2(40.0)$ & $0(0.0)$ & $0(0.0)$ & $0(0.0)$ & $0(0.0)$ & $0(0.0)$ & $0(0.0)$ & 100.0 & 100.0 \\
\hline 9 & $3(42.9)$ & $4(80.0)$ & $3(42.9)$ & $1(20.0)$ & $1(14.3)$ & $0(0.0)$ & $0(0.0)$ & $0(0.0)$ & $0(0.0)$ & $0(0.0)$ & 85.7 & 100.0 \\
\hline 10 & $5(71.4)$ & $4(80.0)$ & $2(28.6)$ & $1(20.0)$ & $0(0.0)$ & $0(0.0)$ & $0(0.0)$ & $0(0.0)$ & $0(0.0)$ & $0(0.0)$ & 100.0 & 100.0 \\
\hline 11 & $2(28.6)$ & $2(40.0)$ & $2(28.6)$ & $3(60.0)$ & $3(42.9)$ & $0(0.0)$ & $0(0.0)$ & $0(0.0)$ & $0(0.0)$ & $0(0.0)$ & 57.1 & 100.0 \\
\hline 12 & $2(28.6)$ & $3(60.0)$ & $3(42.9)$ & $2(40.0)$ & $2(28.6)$ & $0(0.0)$ & $0(0.0)$ & $0(0.0)$ & $0(0.0)$ & $0(0.0)$ & 71.4 & 100.0 \\
\hline 13 & $4(57.1)$ & $3(60.0)$ & $2(28.6)$ & $2(40.0)$ & $1(14.3)$ & $0(0.0)$ & $0(0.0)$ & $0(0.0)$ & $0(0.0)$ & $0(0.0)$ & 85.7 & 100.0 \\
\hline 14 & $5(71.4)$ & $4(80.0)$ & $2(28.6)$ & $1(20.0)$ & $0(0.0)$ & $0(0.0)$ & $0(0.0)$ & $0(0.0)$ & $0(0.0)$ & $0(0.0)$ & 100.0 & 100.0 \\
\hline 15 & $6(85.7)$ & $4(80.0)$ & $0(0.0)$ & $1(20.0)$ & $1(14.3)$ & $0(0.0)$ & $0(0.0)$ & $0(0.0)$ & $0(0.0)$ & $0(0.0)$ & 85.7 & 100.0 \\
\hline Total & $51(48.5)$ & $52(69.3)$ & $36(34.3)$ & $23(30.7)$ & $17(16.2)$ & $0(0.0)$ & $0(0.0)$ & $0(0.0)$ & $1(1.0)$ & $0(0.0)$ & 82.9 & 100.0 \\
\hline
\end{tabular}

Note: $† R 1=$ round $1 ; \ddagger R 2$ = round 2 ; *The CVI was defined as the ratio between the number of items rated "completely adequate" and "adequate" and the total number of assessments performed. Source: the authors.

\section{Discussion}

The exercise booklet was compiled after the need for an educational instrument to support a program of home exercises for children and adolescents in the maintenance or post-treatment phases of ALL was identified in the research project entitled "Effects of physical exercise on the physical fitness and quality of life of children and adolescents with leukemia: a randomized controlled trial". Since chemotherapy sessions are less frequent in the maintenance phase, children can resume their routine activities and begin a program of homebased physical exercise, as can those no longer being treated.

The booklet helps ensure that exercises are performed correctly and prepares both children and their families for a home-based program. The ability to continuously consult the material for guidance favors greater safety, confidence, adherence, comfort and family involvement in the activities, encouraging regular physical exercise. 
Studies have used a home-based approach for physical exercise ${ }^{12,18,19,21}$ considering its long-term viability and maintenance, with more accessible exercise plans that do not require specialized equipment.

The types of exercise and execution stages were selected based on phase 2 and 3 of cardiac rehabilitation guidelines, ${ }^{15,16}$ studies with similar populations and topics, ${ }^{8-12,20,25}$ as well as the medications used during leukemia treatment and their adverse effects.

According to the recommendations of the World Health Organization (WHO), children and adolescents between the ages of five and 17 years should engage in at least 60 minutes of moderate-to-vigorous intensity physical activity a day, most of which should be aerobic, as well as high-intensity activities such as strengthening exercises three times a week. In addition to a planned exercise program, these activities include games, sports, recreation, walking or cycling to school, physical education classes, and community and home-based activities. ${ }^{26}$

These recommendations are generally aimed at healthy children and adolescents, making it essential for adjustments to be made based on disease characteristics, clinical condition, medications used and possible complications in order to safely prescribe exercise for each population.

Authors recommend mild activities for children during the induction and consolidation phases of ALL treatment to help mitigate the negative effects of therapy. Moderate activities are permitted on some days during the maintenance phase, but daily exercise may not be viable, making a gradual progression in daily activities more recommended. As activities increase, the inclusion of strength and resistance exercises helps reduce fatigue, and the involvement of family members is important to ensure adherence regardless of the treatment phase. ${ }^{25}$

In addition to exercises, the booklet analyzed here provides guidance on limitations and contraindications, important in determining when participants should stop exercising or postpone it. Although verbal instructions are more commonly used by healthcare professionals, written materials are important to reinforce these instructions and directly impact teaching effectiveness, facilitating the teaching-learning process and improving treatment adherence, by serving as a guide when questions arise later on, and helping in decision making. ${ }^{27-30}$

Once the booklet was compiled, its content validity was assessed by a panel of experts in the field of health.
The number of healthcare professionals varies between studies; however, a panel of five to ten experts in the instrument's area of knowledge is recommended for quantitative and qualitative assessment. ${ }^{31,32}$

Studies use the content validity index (CVI), considering an index greater than or equal to $80 \%$ as indicative of consensus. ${ }^{28,33,34}$ The minimum acceptable interrater agreement adopted by researchers is $80 \%$, although values above $90 \%$ are preferred. ${ }^{31,32,35}$

Expert opinions are vital in adjusting educational material, improving its rigor and making it more comprehensive and effective, in order to standardize and formalize conduct with the participation of a multiprofessional team by valuing different viewpoints. ${ }^{33,36}$ Although the booklet was deemed validated in the first round, following suggestions and correction by the experts, it was modified and submitted to a second round of assessment.

Educational material should use simple wording with clear and precise information and visually appealing illustrations. When compiling the material, it is important to consider the content, language, organization, layout, illustrations, learning format and motivation. ${ }^{27,28,30}$ It should not be overly long, be objective, easy to understand, and it must meet the needs of the target population. Illustrations are also important, both to make the material more appealing and easily understood. ${ }^{36}$

Suggestions made by the experts included language changes, in particular better communication of technical terminology, especially in the exercise descriptions. The pictures were designed so that parents and their children could immediately grasp the exercise, and accompanied by a description to ensure complete understanding.

It is important that educational material is easily understood by anyone, making it necessary to adjust scientific language to ensure understanding of the concept regardless of schooling level, since professionals often fail to notice the use of technical terminology. ${ }^{36-38}$

Another item highlighted for adjustment was the lack of standardized information on the execution time of the exercises, such as seconds for stretching and number of repetitions in the strength exercises.

This variation was considered when compiling the booklet, since intensity should be modified after two months of training. As a result, the change in intensity was maintained, but the number of repetitions before and after this time period was standardized. The number of repetitions used was based on studies that involve strength exercises with the same population. ${ }^{10,11}$ 
For the stretching exercises, the experts suggested adhering to the standard 30 seconds recommended in the literature. ${ }^{39}$ A time of 20 seconds was adopted in the booklet because longer stretching could deter children and distract them during exercise, potentially compromising adherence. Research varies in regard to the optimal frequency and duration of stretching. A study with children involving 20-second-long static stretching in physical education classes over 16 weeks showed an increase in flexibility. ${ }^{40}$

Few changes were made to the exercises proposed in the booklet, with the exception of improving the positions depicted in the pictures (two exercises), replacing two exercises considered difficult to execute and altering the execution of one. In addition to the expert's opinions, the three children who assessed the booklet played a vital role in improving both the pictures and exercises by identifying positive and negative points during execution.

Illustrations are important in improving understanding of the text and should be clear, accompanied by a description, appropriate for the target audience and communicate a single idea. ${ }^{30}$ Well-designed educational material can influence the reality of the target population, provided it meets their needs and that its contents are in line with what they consider important. ${ }^{37}$

The booklet makes it possible to standardize information, provide guidance and encourage healthy habits through exercise based on the reality and abilities of the target population since, although exercise itself cannot be standardized, it is important to create guidelines and foster initiatives in the area of pediatric oncology.

Limitations of this study include the lack of research in pediatric oncology and physical exercise, particularly home-based programs, making it challenging to compile the exercises considering all the necessary criteria for proper execution. The scarcity of studies that use printed educational material for children or exercises booklets on a different topic limited comparison of the stages involved in compiling the material. Despite this limitation, several investigations ${ }^{28,33,34,41,42}$ provided the necessary support in compiling the booklet and a conceptual framework for its design and validation. ${ }^{30-32,35,36,43,44}$

It is important to note that the goal of the booklet is to help children in the maintenance or post-treatment phase of ALL to perform physical exercise at home and promote a change in their daily habits, directly impacting their quality of life and self-esteem. The exercises should be approved and monitored by the relevant healthcare team.

\section{Conclusion}

The present study compiled a booklet containing 20 home-based exercises aimed at children and adolescents in the maintenance or post-treatment phase of $A L L$, which, after validation of its content by experts, achieved $100 \%$ agreement in the second round of assessment based on the Delphi technique.

The objective of describing the process of compiling and validating the booklet was achieved, and its content was quantitative and qualitatively assessed by a panel of experts and considered valid.

Further research will include clinical validation of the booklet for children and adolescents in the maintenance or post-treatment phase of ALL in order to identify the impact of the home-based exercise program on their quality of life and physical fitness.

\section{Authors' contributions}

REGS was responsible for all stages of the article, namely: the literature review, conceiving and designing the study, data collection, statistical analysis, discussion of the results and conclusion. AFMA, advisor for the thesis that gave rise to the article, was responsible for conceiving and designing the study. Along with RPMS, co-advisor for the thesis, was also responsible for critically analyzing the manuscript, organizing the methodological process, correcting and analyzing all the different stages.

\section{References}

1. Ministério da Saúde. Incidência, Mortalidade e Morbidade hospitalar por câncer em crianças, adolescentes e adultos jovens no Brasil: Informações dos registros de câncer e do sistema de mortalidade [cited 2018 Jun 13]. Available from: https://tinyurl.com/y944tqed

2. Zanichelli MA, Colturato VR, Sobrinho J. Indicações em transplante de células-tronco hematopoéticas em pacientes adultos com leucemia linfoide aguda. Rev Bras Hematol Hemoter. 2010;32(Suppl 1):54-60. DOI 
3. Noronha EP, Marinho HT, Thomaz EBAF, Silva CA, Veras GLR, Oliveira RAG. Immunophenotypic characterization of acute leukemia at a public oncology reference center in Maranhão, northeastern Brazil. Sao Paulo Med J. 2011;129(6):392-401. DOI

4. Hoffman MC, Mulrooney DA, Steinberger J, Lee J, Baker KS, Ness KK. Deficits in physical function among young childhood cancer survivors. J Clin Oncol. 2013;31(22):2799-805. DOI

5. Arpaci T, Kilicarslan Toruner E. Assessment of problems and symptoms in survivors of childhood acute lymphoblastic leukaemia. E Eur J Cancer Care (Engl). 2016;25(6):1034-43. DOI

6. Almeida EMP, Andrade RG, Cecatto RB, Brito CMM, Camargo FP, Pinto CA, et al. Exercise for oncological patients: rehabilitation. Acta Fisiatr. 2012;19(2):82-9. DOI

7. Simioni C, Zauli G, Martelli AM, Vitale M, Ultimo S, Milani D, et al. Physical training interventions for children and teenagers affected by acute lymphoblastic leukemia and related treatment impairments. Oncotarget. 2018;9(24):17199-209. DOI

8. Moyer-Mileur LJ, Ransdell L, Bruggers CS. Fitness of children with standard-risk acute lymphoblastic leukemia during maintenance therapy: response to a home-based exercise and nutrition program. J Pediatr Hematol Oncol. 2009;31(4): 259-66. DOI

9. Beulertz J, Prokop A, Rustler V, Bloch W, Felsch M, Baumann FT. Effects of a 6-month, group-based, therapeutic exercise program for childhood cancer outpatients on motor performance, level of activity, and quality of life: group-based, outpatient exercise intervention. Pediatr Blood Cancer. 2016;63(1):127-32. DOI

10. Perondi MB, Gualano B, Artioli GG, Painelli VS, Odone Filho $V$, Netto $G$, et al. Effects of a combined aerobic and strength training program in youth patients with acute lymphoblastic leukemia. J Sports Sci Med. 2012;11(3):387-92. Full text link

11. San Juan AF, Fleck SJ, Chamorro-Viña C, Maté-Muñoz JL, Moral S, Pérez M, et al. Effects of an intrahospital exercise program intervention for children with leukemia. Med Sci Sports Exerc. 2007;39(1):13-21. DOI

12. Esbenshade AJ, Friedman DL, Smith WA, Jeha S, Pui $\mathrm{CH}$, Robison LL, et al. Feasibility and initial effectiveness of home exercise during maintenance therapy for childhood acute lymphoblastic leukemia. Pediatr Phys Ther. 2014;26(3):301-7. DOI
13. Patti A, Paoli A, Bianco A, Palma A. Pediatric exercise programs in children with hematological cancer: a systematic review. Eur J Sport Studies. 2013;1(2):71-86. DOI

14. Moura IH, Silva AFR, Rocha AESH, Lima LHO, Moreira TMM, Silva ARV. Construction and validation of educational materials for the prevention of metabolic syndrome in adolescents. Rev Lat Am Enfermagem. 2017;25:e2934. DOI

15. Herdy A, López-Jiménez $F$, Terzic $C P$, Milani $M$, Stein $R$, Carvalho $T$, et al. South American Guidelines for Cardiovascular Disease Prevention and Rehabilitation. Arq Bras Cardiol. 2014; 103(2 Suppl 1):1-31. DOI

16. Santos MVC, Paiva MG, Macedo CRDP, Petrilli AS, Azeka E, Jatene IB, et al. I Diretriz Brasileira de Cardio-Oncologia Pediátrica da Sociedade Brasileira de Cardiologia. Arq Bras Cardiol. 2013;100(5 Suppl 1):1-68. DOI

17. San Juan AF, Chamorro-Viña C, Moral S, Fernández del Valle M, Madero L, Ramírez M, et al. Benefits of intrahospital exercise training after pediatric bone marrow transplantation. Int J Sports Med . 2008;29(5):439-46. DOI

18. Tanir MK, Kuguoglu S. Impact of exercise on lower activity levels in children with acute lymphoblastic leukemia: a randomized controlled trial from Turkey. Rehabil Nurs. 2013;38(1):48-59. DOI

19. Marchese VG, Chiarello LA, Lange BJ. Effects of physical therapy intervention for children with acute lymphoblastic leukemia. Pediatr Blood Cancer. 2004;42(2):127-33. DOI

20. Hartman A, Winkel ML, van Beek RD, Keizer-Schrama SMPFM, Kemper HCG, Hop WCJ, et al. A randomized trial investigating an exercise program to prevent reduction of bone mineral density and impairment of motor performance during treatment for childhood acute lymphoblastic leukemia. Pediatr Blood Cancer. 2009;53(1):64-71. DOI

21. Takken $T$, van der Torre $P$, Zwerink $M$, Hulzebos EH, Bierings M, Helders PJM, et al. Development, feasibility and efficacy of a community-based exercise training program in pediatric cancer survivors. Psychooncology. 2009;18(4):440-8. DOI

22. Castro AV, Rezende M. A técnica Delphi e seu uso na pesquisa de enfermagem: revisão bibliográfica. Rev Min Enferm. September 2009;13(3):429-34. Full text link 
23. Scarpo AF, Laus AM, Azevedo ALCS, Freitas MRI, Gabriel CS, Chaves LDP. Reflexões sobre o uso da técnica Delphi em pesquisas na enfermagem. Rev Rene. 2012;13(1):242-51. Full text link

24. Rocha EP. Produção e validação de tecnologia educacional para familiares de crianças com leucemia linfocítica aguda em isolamento protetor [master's thesis]. Manaus, AM: Universidade Federal do Amazonas; 2016. 156 p. Full text link

25. White J, Flohr JA, Winter SS, Vener J, Feinauer LR, Ransdell LB. Potential benefits of physical activity for children with acute lymphoblastic leukaemia. Pediatr Rehabil. 2005;8(1): 53-8. DOI

26. World Health Organization. Global recommendations on physical activity for health. Geneva: World Health Organization; 2010. Full text link

27. Moreira MF, Nóbrega MML, Silva MIT. Comunicação escrita: contribuição para a elaboração de material educativo em saúde. Rev Bras Enferm. 2003;56(2):184-8. DOI

28. Silva RA, Ximenes LB, Cruz AG, Serra MAAO, Araújo MFM, Andrade LM, et al. Atividade sexual na lesão medular: construção e validação de cartilha educativa. Acta Paul Enferm. 2018;31(3):255-64. DO।

29. Kaplún G. Material educativo: a experiência de aprendizado. Comunic \& Educ. 2003;(27):46-60. DOI

30. Hoffmann T, Worrall L. Designing effective written health education materials: Considerations for health professionals. Disabil Rehabil. 2004;26(19):1166-73. DOI

31. Coluci MZO, Alexandre NMC, Milani D. Construção de instrumentos de medida na área da saúde. Cienc Saude Coletiva. 2015;20(3):925-36. DOI

32. Polit DF, Beck CT. The content validity index: Are you sure you know what's being reported? Critique and recommendations. Res Nurs Health. 2006;29(5):489-97. DOI

33. Cordeiro LI, Lopes TO, Lira LEA, Feitoza SMS, Bessa MEP, Pereira MLD, et al. Validation of educational booklet for HIV/ Aids prevention in older adults. Rev Bras Enferm. 2017;70(4): 775-82. DOI
34. Oliveira SC, Lopes MVO, Fernandes AFC. Development and validation of an educational booklet for healthy eating during pregnancy. Rev Lat Am Enfermagem. 2014;22(4): 611-20. DOI

35. Souza AC, Alexandre NMC, Guirardello EB. Psychometric properties in instruments evaluation of reliability and validity. Epidemiol Serv Saude. 2017;26(3):649-59. DOI

36. Echer IC. Elaboração de manuais de orientação para o cuidado em saúde. Rev Latino-Am Enfermagem. 2005;13(5):754-7. DOI

37. Zombini EV, Pelicioni MCF. Estratégias para a avaliação de um material educativo em saúde ocular. Rev Bras Crescimento Desenvolv Hum. 2011;21(1):51-8. Full text link

38. Griffin J, McKenna K, Tooth L. Written health education materials: Making them more effective. Aust Occup Ther J. 2003;50(3):170-7. DOI

39. Almeida PHF, Barandalize D, Ribas DIR, Gallon D, Macedo ACB, Gomes AR. Alongamento muscular: suas implicações na performance e na prevenção de lesões. Fisioter Mov. 2009;22(3):335-43. Full text link

40. Coledam DHC, Arruda GA, Oliveira AR. Chronic effect of static stretching performed during warm-up on flexibility in children. Rev Bras Cineantropom Desempenho Hum. 2012;14(3):296-304. DOI

41. Farias MS, Ponte KMA, Gomes DF, Menezes RSP. Tecnologia educativa sobre câncer gástrico. J Nurs UFPE on line. 2018;12 (4):947-52. DOI

42. Aquino JA, Baldoni AO, Oliveira CL, Figueiredo RC, Cardoso $\mathrm{CS}$, Pereira ML, et al. Cartilha educativa sobre diabetes: elaboração e validação de conteúdo. Semina: Cienc Biol Saude. 2016;37(1):77-82. DOI

43. Matos DAS. Confiabilidade e concordância entre juízes: aplicações na área educacional. Est Aval Educ. 2014;25(59): 298-324. DOI

44. Alexandre NMC, Coluci MZO. Validade de conteúdo nos processos de construção e adaptação de instrumentos de medidas. Cienc Saude Coletiva. 2011;16(7):3061-8. DOI 